\title{
Original Research Paper Physical Education \\ EFFECT OF YOGIC PRACTICES AND PHYSICAL EXERCISES ON LOW DENSITY LIPOPROTEIN OF URBAN OBESE BOYS STUDENT
}

\section{A. Vidhya}

\section{Dr. K. Usha Rani*}

Ph.D Scholar, Department Of Physical Education And Health Sciences Alagappa University, Karaikudi.

Professor, Department Of Physical Education And Health Sciences Alagappa University, Karaikudi. *Corresponding Author

ABSTRACT The purpose of the study is to find out the effects of yogic practices and physical exercises on Low Density Lipoprotein of urban obese boys student. Forty five healthy, untrained students were selected from various schools in Madurai. The subject's age ranged from 13 to 15 years. The chose subjects were isolated into three gatherings with fifteen subjects in each gathering. The training periods of experimental groups were six weeks, three alternative days per week with duration of 60 minutes. Control group did not undergo any training programme rather than their routine work. Pre tests were conducted for all the 45 subjects on selected Low Density Lipoprotein variable. After the experimental period of six weeks post test were conducted immediately. To study the effect of yogic practices group and physical exercises training group along with control group and to find out the significant mean differences among them, the analysis of covariance (ANCOVA) technique were used. Scheffe's test was pursued as a post hoc test to figure out which of the matched methods distinction was noteworthy. The 0.05 level of confidence was fixed to test the level of significance which was considered as an appropriate. The results of the study were concluded that there was significant improvement in selected variable.

\section{KEYWORDS :}

\section{INTRODUCTION}

Yoga means to "trouble" to "combine" to bind to "interface" to relate or to "merge". As weight consolidates two bulls, the yoga combines body and brain. The merger of soul with God, and the experience of solidarity with him is yoga.

Physical exercise is any genuine development that updates or keeps up physical wellbeing and all around prosperity and wellbeing. It is performed for various reasons including bracing muscles and the cardiovascular structure, honing athletic aptitudes, weight decrease or backing, similarly likewise with the ultimate objective of joy.

Low-thickness lipoproteins (LDL) contain a higher proportion of cholesterol to protein and are thought of as the "awful" cholesterol. Raised levels of LDL lipoprotein increment the danger of coronary illness, stroke, and fringe conduit sickness, by helping structure cholesterol plaque along within supply route dividers. After some time, as plaque development (plaque stores) builds, the conduit limits (atherosclerosis) and blood stream diminishes. On the off chance that the plaque cracks, it can cause a blood coagulation to frame that forestalls any blood stream. This coagulation is the reason for a respiratory failure or myocardial localized necrosis if the RESULTS AND DISCUSSION

Table-l: Analysis of Covariance for the Pre, Post and Adjusted Post Test Means Values for Control Group, Yogic Practices Group and Physical exercises Group on Low Density Lipoprotein (mg/dL)

\begin{tabular}{|c|c|c|c|c|c|c|c|c|c|}
\hline Test & Control Group & $\begin{array}{c}\text { Yogic Practices } \\
\text { Group }\end{array}$ & $\begin{array}{c}\text { Physical exercises } \\
\text { Group }\end{array}$ & S V & S S & D f & M S & $\begin{array}{c}\text { F } \\
\text { ratio }\end{array}$ & $\begin{array}{c}\text { Table } \\
\text { Value }\end{array}$ \\
\hline Pre Test Mean & 183.87 & 185.07 & 182.27 & B w & 59.2 & 2 & 29.6 & 0.504 & 3.22 \\
\cline { 5 - 10 } & & & & W n & 2467.6 & 42 & 58.75 & & \\
\hline Post Test Mean & 187.27 & 182.93 & 177.05 & B w & 789.39 & 2 & 394.69 & $10.12^{*}$ & 3.22 \\
\cline { 5 - 10 } & & 182.09 & 177.97 & W n & 1638.7 & 42 & 39.02 & & \\
\cline { 5 - 10 } $\begin{array}{c}\text { Adjusted Post } \\
\text { Test Mean }\end{array}$ & 187.18 & & & W n & 652.21 & 41 & 15.91 & & 3.23 \\
\hline
\end{tabular}

${ }^{*}$ Significant at 0.05 level of confidence

The table-l shows that the pre test mean values on Low Density Lipoprotein of control group, yogic practices group and physical exercises group were 183.87 , 185.07 and 182.27 respectively. The obtained ' $F$ ' ratio 0.504 for pre test mean was less than the table value 3.22 for $\mathrm{df} 2$ and 42 required for significance at 0.05 coagulation happens in one of the coronary conduits in the heart.

\section{METHODOLOGY}

The purpose of the study is to find out the effects of yogic practices and physical exercises training on Low Density Lipoprotein of urban obese boys student. The selected subjects were divided into three groups with fifteen subjects in each group selected randomly, with two experimental groups and one control group. Experimental Group I underwent the yogic training selected asanas and pranayama. Experimental Group II underwent the selected physical exercise training in selected running, aerobic exercises, skipping and stretching. The training periods of experimental groups were six weeks, three alternative days per week with training programme rather than their routine work. All the groups were tested on selected criterion variable such as Low Density Lipoprotein prior to and immediately after the training programme. Low Density Lipoprotein was assumed by the lab test. The analyses of covariance (ANCOVA) were used to find the significant difference if any, among the experimental groups and control group on selected criterion variable. duration of 60 minutes. Control group did not undergo any insignificant. The post test mean values on Low Density Lipoprotein of control group, yogic practices group, physical exercises group were 187.27, 182.93 and 177.05 respectively. The obtained 'F' ratio 10.12 for post test mean was greater than the table value 3.22 for $\mathrm{df} 2$ and 42 required for significance at 0.05 level of confidence on Low Density Lipoprotein. Hence it 
was significant. The adjusted post test means of control group, yogic practices group and physical exercises group were $187.18,182.09$ and 177.97 respectively. The obtained 'F' ratio 19.94 for adjusted post -test mean was greater than the table value 3.23 for df 2 and 41 required for significance at 0.05 level of confidence Low Density Lipoprotein. Since the obtained 'F' ratio value was significant further to find out the paired mean difference, the Scheffe's post hoc test was employed and presented in table -ll

Table-ll: The Scheffe's Test for the Difference between Paired Means on Low Density Lipoprotein (mg/dL)

\begin{tabular}{|c|c|c|c|c|}
\hline \multicolumn{3}{|c|}{ Means } & $\begin{array}{c}\text { Mean } \\
\text { Difference }\end{array}$ & $\begin{array}{c}\text { Required } \\
\text { CI }\end{array}$ \\
\hline $\begin{array}{c}\text { Control } \\
\text { Group }\end{array}$ & $\begin{array}{c}\text { Yogic } \\
\text { Practices } \\
\text { Group }\end{array}$ & $\begin{array}{c}\text { Physical } \\
\text { Exercises } \\
\text { Group }\end{array}$ & & \\
\hline 187.18 & 182.09 & - & $5.09^{*}$ & 3.69 \\
\hline 187.18 & - & 177.97 & $\mathbf{9 . 2 1}^{*}$ & \\
\hline- & 182.09 & 177.97 & $4.12^{*}$ & \\
\hline
\end{tabular}

* Significant at 0.05 level of confidence

Table-ll shows the significant difference of paired adjusted post test means of control group, yogic practices group, and physical exercises group on Low Density Lipoprotein. The obtained mean differences between control group, yogic practices group and physical exercises training group were $5.09,9.21$ and 4.12 respectively. The required confidence interval value was 3.69 .

Since the obtained mean differences between control group and experimental groups were greater than the obtained confidence interval value Low Density Lipoprotein, it was concluded that yogic practices group and physical exercises group improved the Low Density Lipoprotein better than the control group. Further it was concluded that the physical exercises group improved the Low Density Lipoprotein better than yogic practices group.

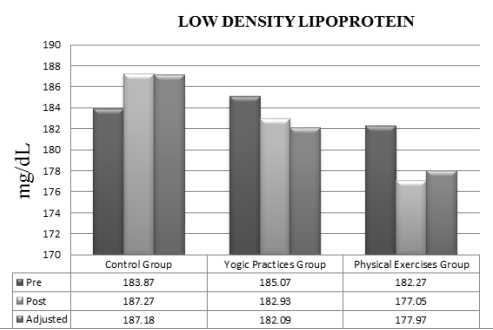

Figure -1ll: Bar Diagram Showing the Pre, Post and Adjusted Post Test Mean Values of Control Group, Yogic Practices Group and Physical Exercises Group on Low Density Lipoprotein

\section{CONCLUSIONS}

1. It was concluded from the results of the study that the yogic practices and physical exercises groups showed significant improvement in Low Density Lipoprotein when compared with a control group.

2. Physical exercises training were a suitable training system to improve the Low Density Lipoprotein among the obese boys student.

\section{REFERENCES}

1. Ben Ounis, Elloumi, M. Ben Chiekh, I. Zbidi, A. Amri, m. Lac, G. Tabka, Z. Impacts of two-month physical-perseverance and diet-confinement programs on lipid profiles and insulin opposition in fat pre-adult young men Diabetes and Metabolism, Vol. 34, No. 6, December 2008. Pp.595-600.

2. Datillo, A.M. furthermore, Kris-Etherton, P.M., (1992), "Impacts of weight Reduction on Blood Lipids and Lipoproteins: A meta-examination, Americaln Journal of Clinical Nutrition, 56, pp.320-328.

3. Dattilo, AM. and Kris-Etherton, PM., (1992), "Effects of Weight Reduction on Blood Lipids and Lipoproteins: A Meta- Analysis", American Journal of Clinical Nutrition, 56(2), pp.320-328. 